\title{
SENSE OF GENDER IDENTITY IN WOMEN PRACTICING FOOTBALL WITH CONSIDERATION OF THE FORMATION
}

\author{
Sexual identity of female football players
}

\author{
ANDRZEJ SOROKA ${ }^{1}$, JÓZEF BERGIER ${ }^{2}$ \\ 1 Pope John Paul II State School of Higher Education in Biata Podlaska \\ 2 The Josef Pilsudski University of Physical Education in Warsaw, Faculty of Physical \\ Education and Sport in Biała Podlaska
}

Mailing address: Andrzej Soroka, Pope John Paul II State School of Higher Education, 95/97 Sidorska Street,
21-500 Biała Podlaska, tel.: +48 501232151, fax: +48 83 3449950, e-mail: wachmistrz_soroka@o2.pl

\begin{abstract}
Introduction. Identification of gender is one of the most important dimensions of building a sense of self-identity; it is also one of the basic criteria for identifying individuals by society. The aim of this study was to determine the types of psychological gender football female players (taking into account the formation), i.e. the sport deemed "masculine". Material and methods. The research group was composed of the female players of the Polish national football team, seniors ( $\mathrm{n}=26)$, youth team under the age of $19(\mathrm{n}=21)$ and the Polish extra league club athletes $(\mathrm{n}=16)$. The tool research was the "Inventory to assess psychological gender (IPP)" by Kuczyńska. Results. Nearly 70\% female football players were included in the androgynous type, while $20 \%$ were the persons representing the so-called specified psychological type. The most important feature identifying cultural gender patterns, selected by the female players was "tolerant" - feature of the cultural stereotype known to be neutral, as well as the characteristics attributed to both women and men: "friendly" and "nice". Conclusion. The studies allow for determining the dominant type of psychological gender of female players as androgynous, which is highly expressed combined male and female characteristics.
\end{abstract}

Key words: psychological sex, women's football

\section{Introduction}

Creation of sports by women, and especially the desire to practice football, so much "male" sport discipline, to the seventies of the last century were treated as a specific activity of the female sex. After the undoubted propaganda success of the first football game played by the ladies in the early twentieth century, in 1921 the English Football Federation has banned women's participation in football competitions. It was withdrawn in 1971 [1] and as early as in 1972 women's football was included in the structure of a European federation. Today, millions of girls around the world, grouped in 129 national federations, participate in regular international and league games [2]. The national championship, world championships and championships of different continents are organized. Since 1996, the women football has become an Olympic sport. This phenomenon undoubtedly arouses admiration in recent years and also raises the question what inspires and encourages women to participate in this sport in such a large number?

It is believed that in our cultural circle the freedom of choice of behaviour, profession or roles, especially for women, is equally limited by both natural factors and social stereotypes [3]. The cause, which undoubtedly made it easier for women to return to practice football, was systematic departure from the constraint of rigid social roles im- posed by a society, which was limited and was opposite to comprehensive and complete development [4]. Not only football, but widely understood sport was one of the last bastions of traditional social order discriminating femininity [5]. It is emphasized that for the marginalized community of women sport may be a chance of social advancement and appreciation [6]. Gender identity is defined as the identification of individuals with a particular social role the system of rules, expectations and expected behaviours that society has towards women and men. Assimilated in childhood social role usually has a strong impact on individual's preferences. The roles performed by men and women consist of some fixed elements from their biological conditions and the changing elements depending on the culture in which they live [7]. Typical characteristics attributed to women were identified, such as: emotional, caring, sensitivity to the needs of others, the ability to sacrifice, submissiveness and warmth in relationships with others; and the characteristics commonly attributed to men, namely: competence, rationality, independence, aggressiveness, confidence, ease of decision-making and not giving up in difficult situations [8]. Currently, it is suggested to reject the traditional model of social roles in favour of androgynity, which involves conscious overcoming social expectations of gender and declaration that men can show motives, attitudes or behaviour of their choice, not of the 
environment [4]. According to Bem [9], every human being should be encouraged to know how to act effectively and express their feelings, to be firm and yielding, masculine and feminine - depending on the situation.

Identification of gender is, therefore, one of the most important dimensions of building a sense of self-identity; it is also the basic criteria for identifying individuals by society. The boundaries of gender identity are for many people very inflexible, and attempt to cross them face fierce resistance and rigidity of attitude of both the individual and the community in which they function [10]. Psychological sex of man is understood as a spontaneous willingness to use the gender dimension in relation to each other and the world [11].

In the literature there are four main configurations of mental characteristics of gender defined as types of psychological gender.

The sex-typed persons are characterized by mental characteristics corresponding to their biological sex (feminine female and masculine male) [11]. People with this type of psychological gender more often than androgynous individuals choose behaviours consistent with their gender scheme. In the case of conduct contrary to their own scheme they feel frustration and disapproval [12]. These are people, whose processes of collection and processing of information and behaviour control are based on social definitions of femininity and masculinity [11]. Units identifying themselves with the traditional attribution of the role of their gender present a more rigid behavioural repertoire that is limited in many respects. It was found that masculine boys and feminine girls have lower intelligence, lower spatial imagination and creative skills than boys with feminine features and girls with masculine features [13].

Androgynous persons are characterized to a large extent by both masculine and feminine features, regardless of their biological sex [11]. Psychological androgyny is the integration and complementarity of male and female elements in the personality. Research confirms that androgynous individuals exhibit a high flexibility of response and richer repertoire of behaviours. They reveal conduct, which at the moment seem to be most effective. Androgynous individuals are dominative, emotional, more resistant to stress. They have a positive self-image, higher self-esteem, better health and a stronger personality [13]. Bem [14] suggests that the androgynous persons, compared with those presenting other types of psychological gender have greater possibilities of constructive action. It is therefore proposed to consider psychological androgyny the type appropriate for mental health to serve as a model of psychological gender.

Persons sexually undefined, (undifferentiated) include those that are slightly shaped male and female features (regardless of their biological sex) [11]. Persons undifferentiated in comparison to sexually androgynous people have lower self-esteem, provide less personal information, show less openness, and are characterized by lower sensitivity and protectiveness towards helpless creatures [12]. Studies have shown that people who do not have formed feminine or masculine personality features show a lot of deficits in social situations and may have adjustment problems [13].

Cross-sex-typed, sex-reversed persons include those that are characterized by mental features corresponding to the sex opposite to the biological sex (feminine males and masculine females) [11]. Masculine women also show high level of competence in both instrumental and expressive tasks, 'feminine' males - advantage of orientation in the tasks of the instrumental type. Women described as typical show greatest inhibition in social relations requiring competence in both instrumental and expressive roles [13].

The concept of gender schemes does not allow predicting that the entity sexually referred to will differ from other people wherever possible, but that it will be different from them by threshold of spontaneous organization of information based on the gender dimension and by motivation for seeking compatibility between their own behaviour and cultural definitions of femininity and masculinity [14].

The aim of this study was to identify types of psychological gender, which are predominant among the athletes professionally practicing football. Efforts were also made to characterize female players playing in different formations and show which features the athletes playing professional football use to the largest extent, saying, or thinking about themselves. Also in this case, the study was carried out with in distribution into field formations.

Due to the requirements of effective games related to the practice of football, which is characterized by order, determination, making quick decisions, aggressiveness, and not giving up in difficult situations, and especially the attitude focused on success, it was hypothetically assumed that football at national level is played by women who, in their behaviour, represent the characteristics of both sexes, i.e. androgynous people, and that the determination of gender identity may indicate women more predisposed to engage in this sport. Efforts were also made to answer the question: what characteristics identify the gender cultural patterns dominate among female football players of the highest sporting competence?

\section{Material and methods}

The study was conducted in the first half of 2010 during the training consultations of both Polish representations and acclimatization session of the Polish extra league. The study covered 63 players, of which 21 were the representatives of Polish national football team under the age of 19, 26 were senior Polish official representatives, and 16 representatives of one of the extra league clubs. Among them there were 8 goalkeepers, 19 played in the defense formation, 24 in halfback and 12 in the forward line. All tested individuals were adult female players with an average age of $22.5 \pm$ 0.8 years. The oldest were the players of extra league team where the average age was $24.3 \pm 4.9$, while the youngest 
were players of Polish national team under the age of 19 $18.6 \pm 0.7$ years. The longest history of playing had the players of Polish national team, seniors $-11.8 \pm 4.9$ (Tab. 1).

Table 1. Age and experience of female football players submitted to survey

\begin{tabular}{|l|c|c|}
\hline \multicolumn{1}{|c|}{ Team category } & $\begin{array}{c}\text { Age } \\
\mathrm{X} \pm \mathrm{SD}\end{array}$ & $\begin{array}{c}\text { Experience } \\
\mathrm{X} \pm \mathrm{SD}\end{array}$ \\
\hline Representation of Poland - seniors & $23.8 \pm 4.6$ & $11.8 \pm 4.9$ \\
\hline Representation of Poland U-19 & $18.6 \pm 0.7$ & $6.8 \pm 3.2$ \\
\hline Polish Extra League team & $24.3 \pm 4.9$ & $10.4 \pm 6.4$ \\
\hline
\end{tabular}

In order to determine types of psychological gender, the research tool used was "Inventory to assess psychological gender (IPP)" by Kuczyńska, which was developed on the basis of gender schema theory (BSRIA) Bem [11]. According to Kuczynska [11], the psychological sex is inherently variable associated with the cultural stereotype of femininity and masculinity operating in a given society, therefore, for the Poles it was not possible to simply adapt the U.S. testing and a tool that would reflect the Polish socio-cultural standards needed to be constructed.

IPP consists of 35 statements, 15 of which present the cultural stereotype of femininity, and 15 cultural stereotypes of masculinity. The other five are buffer positions, equally attributed to both genders. The paper separately analyzed and compared various characteristics by determining the frequency of choice. The answer sheet consisted of a 5-point rating scale, from the degree of "I' $\mathrm{m}$ absolutely not like that" to the "that is what I am." The study was conducted in a group form, anonymously, and the only differentiating criterion was identification of the formation, in which players played in the field. The time allowed for response was not limited, but usually did not last longer than 10 minutes. The obtained results were statistically analyzed using Statistica program. When examining the variations of different intensities of response between individual formations, way analysis of variance (ANOVA) was used for single classification, after prior meeting the requirements for using parametric tests. When demonstrating significant difference, the test Post-hoc was used. Differentiation was determined as statistically significant at $p<0.05$.

\section{Results}

\section{Types of psychological gender of female football players}

Tested female players were in $68.3 \%$ included into the androgynous type, as in the assessment of psychological gender regardless of their biological gender they declared high values in both the scale of femininity and masculinity. Most of the players, who are characterized by androgyny, occurred in the Polish extra league team - 81.1\%. Among the senior Polish players $-69.2 \%$ reached these proportions, while the smallest percentage occurred among youth players of the Polish national team under 19 years $-57.1 \%$. In
$17.5 \%$ of female players were characterized as sexually specified. The largest group of this type of psychological gender was the official youth Polish representation players - 33.3\%, Polish representation senior female players $11.5 \%$, and the players from the Polish extra league $-6.3 \%$. Negligible amount of respondents expressed the concept of them themselves as cross-sex-typed, i.e. they received high scores on a scale corresponding to the opposite sex, and low in the scale of their own $-9.5 \%$ and so called undifferentiated (low scores on a scale of femininity and masculinity) $-4.5 \%$ (Fig. 1 and 2).

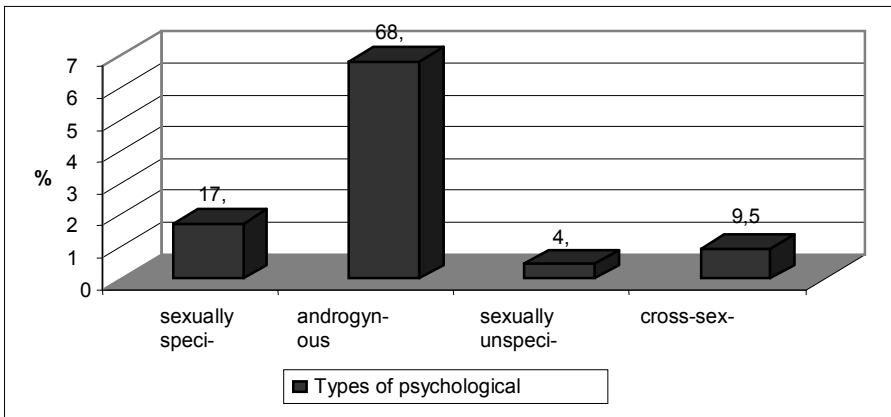

Figure 1. Types of psychological gender of female football players

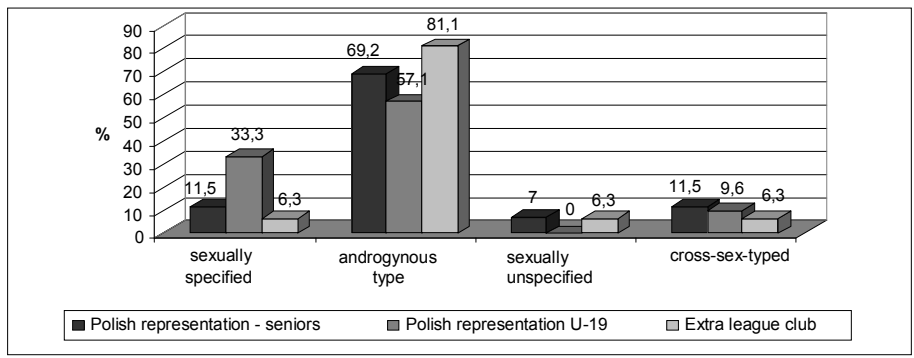

Figure 2. Types of psychological gender of Polish representation senior, U-19 and extra league club female football players

Comparing the types of psychological gender characterizing individual formations, the greatest degree of androgynity was found among the forward players $-83.4 \%$. In other formations, the index was similar: goalkeepers $66.6 \%$, defenders $-63.2 \%$, and halfback $-62.5 \%$. With the overall percentage of women sexually defined (feminine females) constituting $17.5 \%$, in the defense formation there occurred $21.1 \%$, the midfield $20.8 \%$, while the forward formation to $8.3 \%$. The largest proportion of players assigned to an undifferentiated sexual type there occurred in line of defense $-10.5 \%$, while the cross-sex-typed (masculine female) in the formation of goalkeepers $-16.7 \%$ and halfback $-12.5 \%$ (Fig. 3). 


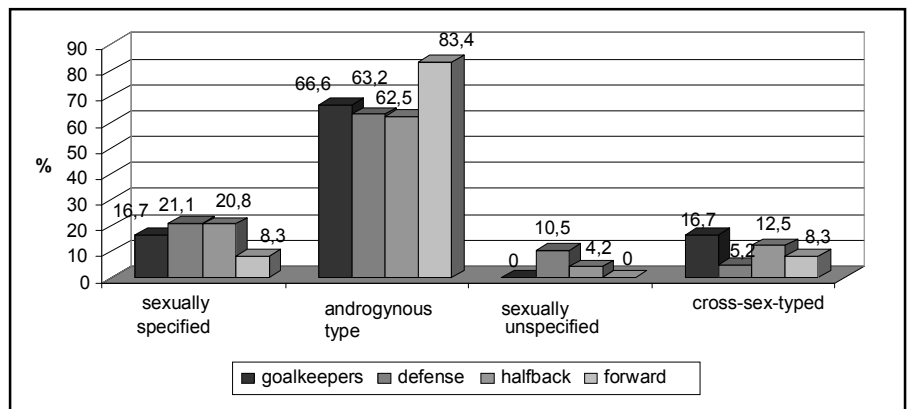

Figure 3. Types of psychological gender of female football players depending on formation

\section{Psychological features of female football players}

Of the 35 statements contained in the IPP, which clearly characterize the stereotype of male and female, and the characteristics attributed to both genders as a neutral, five are highlighted, which had the highest and lowest average value in the 5-point scale score. The highest average that defined the players as "I am almost like that" was received by neutral features, such as "tolerant" $4.52 \pm 0.56$, and "friendly" $4.34 \pm 0.62$ points. Equally high values reached features ascribed to women: "emotional" $4.49 \pm$ 0.69 , and "sensitive" $4.31 \pm 0.56$, and a feature known to be the stereotype of masculinity, i.e. "focused on success" 4.26 \pm 0.51 points (Tab. 2 ).

Table 2. Identification and its absence in self-description of gender dimension

\begin{tabular}{|c|c|c|c|}
\hline \multicolumn{3}{|c|}{ Readiness to use gender dimension in self-description } \\
\hline \multicolumn{2}{|c|}{ Identification } & \multicolumn{2}{c|}{ No identification } \\
\hline Feature & $\mathrm{X} \pm \mathrm{SD}$ & Feature & $\mathrm{X} \pm \mathrm{SD}$ \\
\hline Tolerant $(\mathrm{N})$ & $4.52 \pm 0.56$ & Arrogant $(\mathrm{M})$ & $1.85 \pm 0.81$ \\
\hline Affectionate $(\mathrm{F})$ & $4.49 \pm 0.69$ & Naive $(\mathrm{F})$ & $2.33 \pm 0.69$ \\
\hline Friendly $(\mathrm{N})$ & $4.34 \pm 0.59$ & Grumpy $(\mathrm{F})$ & $2.39 \pm 0.54$ \\
\hline Emotional $(\mathrm{F})$ & $4.31 \pm 0.71$ & Flirtatious $(\mathrm{F})$ & $2.79 \pm 0.73$ \\
\hline Focused on success $(\mathrm{M})$ & $4.26 \pm 0.51$ & Dominant $(\mathrm{M})$ & $2.98 \pm 0.82$ \\
\hline
\end{tabular}

$\mathrm{F}$ - features described as feminine

$\mathrm{M}$ - features described as masculine

$\mathrm{N}$ - features described as neutral

The lowest approval of the claim that "I'm not like that" or "I am like that to a small extent", gained the features included in the stereotype of masculinity: "arrogant" $1.85 \pm 0.81$ and "dominant" $2.98 \pm 0.82$, and the stereotypical female features such as "naive" $2.33 \pm 0.69$, "grumpy" $2.39 \pm$ 0.54 and "flirtatious" $2.79 \pm 0.73$ points (Tab. 2).

The concentration of characteristics defining both male and female stereotype differentiated players of various formations. Masculine feature, i.e. "focus on success" was of high importance among the forward players $4.75 \pm 0.71$, defense $4.36 \pm 0.76$, and goalkeepers $4.16 \pm 0.75$ (Tab. 3, 4 and 6). An important position among goalkeepers $4.66 \pm$
0.51 , defenders $4.36 \pm 0.76$ and forwards $4.41 \pm 0.61$, also had "sense of humour" considered to be a masculine feature, and characterizing feature of both the stereotype of femininity and masculinity: "tolerant", which reached the average among goalkeepers $4.66 \pm 0.50$, among the defenders $4.57 \pm 0.60$ and in the case halfbacks $4.36 \pm 0.51$ (Tab. 3, 4,5 and 6). In the formation of defense high levels were reached by characteristics attributed to the stereotype of femininity: "emotional" and "sensitive" which in this group reached the average level: $4.42 \pm 0.60$ and $4.31 \pm 0.58$. Also, these typical characteristics attributed to women have been exhibited by female players of halfback line: "sensitive" $4.57 \pm 0.71$, "emotional" $4.42 \pm 0.61$ and "caring" $4.31 \pm$ 0.83 , and "emotional" $4.50 \pm 0.79$ also in the case of forwards (Tab. 5). In examining the characteristics of individual formation one cannot help but notice exhibited by the female players self-determination of "nice" and "responsible", the characteristics attributed to both women and men that have been listed among the five most important features by goalkeepers, respectively: "nice" \pm 4.330 .51 and "responsible" $4.16 \pm 0.42$. The latter feature has acquired considerable strength in the case forwards $4.33 \pm 0.65$. Also generically neutral feature, which is "friendly" has gained acceptance among halfback formation $4.34 \pm 0.65$ and forwards $4.41 \pm 0.51$ (Tab. 3, 4 and 6).

Table 3. Identification and its absence in self-description of gender dimension by goalkeepers

\begin{tabular}{|l|l|l|l|}
\hline \multicolumn{4}{|c|}{ Features characteristic for the female football players } \\
\hline \multicolumn{2}{|c|}{ Confirmation of gender stereotype } & \multicolumn{2}{c|}{ Negation of gender stereotype } \\
\hline \multicolumn{1}{|c|}{ Feature } & \multicolumn{1}{c|}{$\mathrm{X} \pm \mathrm{SD}$} & \multicolumn{1}{c|}{ Feature } & $\mathrm{X} \pm \mathrm{SD}$ \\
\hline $\begin{array}{l}\text { With sense of humour } \\
\text { (M) }\end{array}$ & $4.66 \pm 0.51$ & Arrogant (M) & $1.66 \pm 0.81$ \\
\hline Tolerant (N) & $4.66 \pm 0.50$ & Grumpy (F) & $1.83 \pm 0.75$ \\
\hline Nice (N) & $4.33 \pm 0.51$ & Naive (F) & $2.00 \pm 0.82$ \\
\hline Responsible (N) & $4.16 \pm 0.42$ & Flirtatious (F) & $2.83 \pm 1.01$ \\
\hline Focused on success (M) & $4.16 \pm 0.75$ & Dominant (M) & $3.00 \pm 0.88$ \\
\hline
\end{tabular}

$\mathrm{F}$ - features described as feminine

$\mathrm{M}$ - features described as masculine

$\mathrm{N}$ - features described as neutral

Table 4. Features confirming and negating the femininity stereotype of female football players of defense formation

\begin{tabular}{|l|l|l|l|}
\hline \multicolumn{4}{|c|}{ Features characteristic for the female football players } \\
\hline Confirmation of gender stereotype & \multicolumn{2}{|l|}{ Negation of gender stereotype } \\
\hline Feature & $\mathrm{X} \pm \mathrm{SD}$ & Feature & $\mathrm{X} \pm \mathrm{SD}$ \\
\hline Tolerant $(\mathrm{N})$ & $4.57 \pm 0.60$ & Arrogant $(\mathrm{M})$ & $2.00 \pm 0.81$ \\
\hline Emotional $(\mathrm{F})$ & $4.42 \pm 0.60$ & Grumpy $(\mathrm{F})$ & $2.36 \pm 0.89$ \\
\hline $\begin{array}{l}\text { With sense of humour } \\
(\mathrm{M})\end{array}$ & $4.36 \pm 0.76$ & Flirtatious (F) & $2.42 \pm 1.01$ \\
\hline Focused on success (M) & $4.34 \pm 0.62$ & Naive (F) & $2.47 \pm 0.90$ \\
\hline Sensitive (F) & $4.31 \pm 0.58$ & Dominant (M) & $2.84 \pm 0.74$ \\
\hline
\end{tabular}

$\mathrm{F}$ - features described as feminine

$\mathrm{M}$ - features described as masculine

$\mathrm{N}-$ features described as neutral 
Table 5. Features confirming and negating the femininity stereotype of female football players of halfback formation

\begin{tabular}{|l|c|l|c|}
\hline \multicolumn{4}{|l|}{ Features characteristic for the female football players } \\
\hline \multicolumn{2}{|l|}{ Confirmation of gender stereotype } & \multicolumn{2}{l|}{ Confirmation of gender stereotype } \\
\hline \multicolumn{1}{|c|}{ Feature } & $\mathrm{X} \pm \mathrm{SD}$ & \multicolumn{1}{|l|}{ Feature } & $\mathrm{X} \pm \mathrm{SD}$ \\
\hline Affectionate (F) & $4.57 \pm 0.71$ & Arrogant (M) & $1.83 \pm 0.81$ \\
\hline Emotional (F) & $4.42 \pm 0.61$ & Naive (F) & $2.41 \pm 0.98$ \\
\hline Tolerant (N) & $4.36 \pm 0.51$ & Grumpy (F) & $2.58 \pm 1.01$ \\
\hline Friendly (N) & $4.34 \pm 0.65$ & Dominant (M) & $2.92 \pm 0.92$ \\
\hline Caring (F) & $4.31 \pm 0.83$ & Flirtatious (F) & $2.97 \pm 0.74$ \\
\hline
\end{tabular}

$\mathrm{F}$ - features described as feminine

$\mathrm{M}$ - features described as masculine

$\mathrm{N}$ - features described as neutral

Table 6. Features confirming and negating the femininity stereotype of female football players of forward formation

\begin{tabular}{|l|c|l|c|}
\hline \multicolumn{4}{|c|}{ Features characteristic for the female football players } \\
\hline \multicolumn{2}{|c|}{ Confirmation of gender stereotype } & \multicolumn{2}{c|}{ Negation of gender stereotype } \\
\hline \multicolumn{1}{|c|}{ Feature } & $\mathrm{X} \pm \mathrm{SD}$ & \multicolumn{1}{c|}{ Feature } & $\mathrm{X} \pm \mathrm{SD}$ \\
\hline Focused on success (M) & $4.75 \pm 0.71$ & Arrogant (M) & $1.75 \pm 0.84$ \\
\hline Emotional (F) & $4.50 \pm 0.79$ & Naive (F) & $1.94 \pm 0.86$ \\
\hline $\begin{array}{l}\text { With sense of humour } \\
\text { (M) }\end{array}$ & $4.41 \pm 0.61$ & Grumpy (F) & $2.41 \pm 0.79$ \\
\hline Friendly (N) & $4.41 \pm 0.51$ & Flirtatious (F) & $2.75 \pm 0.98$ \\
\hline Responsible (N) & $4.33 \pm 0.65$ & Dominant (M) & $2.91 \pm 1.02$ \\
\hline
\end{tabular}

$\mathrm{F}$ - features described as feminine

$\mathrm{M}$ - features described as masculine

$\mathrm{N}-$ features described as neutral

The highest degree of non-acceptance was received among the players by characteristics of the male stereotype such as "arrogant" and "dominant". Players of all formations commented that "I'm not like that" or "I'm nearly not like that" in the case of the term "arrogant": goalkeepers $1.66 \pm 0.81$, forwards $1.75 \pm 0.84$, halfbacks $1.83 \pm 0.81$, and defenders $2.00 \pm 0.81$. Another typical male feature i.e. "dominant" was not acceptable to a large extent by the female players of all formations by the statement "I'm rather not like that" or "I'm like that to the average degree": halfback female players $2.84 \pm 0.74$, forwards $2.91 \pm 1.02$, halfbacks $2.94 \pm 0.74$ and goalkeepers $3.00 \pm 0.88$ (Tab. $3,4,5$ and 6).

In the group of non-acceptable features, as "I'm absolutely not like that", "I'm rather not like that" and "I'm like that to a minimal degree" there was the term "grumpy": goalkeepers $1.83 \pm 0.75$, defenders $2.36 \pm 0.89$, forwards 2.41 \pm 0.79 and halfbacks $2.58 \pm 1.01$, and "naive" a feature not approved by players of all formations: forwards $1.94 \pm 0.86$, goalkeepers $2.00 \pm 0.82$, halfbacks $2.41 \pm 0.98$ and defense $2.47 \pm 0.90$, as well as "flirtatious": defenders $2.42 \pm 1.01$, forwards $2.75 \pm 0.98$, goalkeepers $2.83 \pm 1.01$ and halfbacks $2.97 \pm 0.74$ (Tab. 3, 4, 5 and 6).

Significant differences between players of individual formation (at the level $p<0.05$ ) were found for such characteristics as "focused on success", where the forwards have reached a higher value compared to other formations, "confident" as a feature that differentiated the formation of de- fense and forward. It should be noted that the two features belong to the male stereotype. The characteristics attributed to the stereotype of femininity such as "engaging in the affairs of others" and "sensitive" for halfbacks reached significantly higher values than in case of other formations, and "able to make sacrifices," differentiated significantly goalkeepers and formation of defense (Tab. 7).

Table 7. Differentiation of features defining the personality depending on formation

\begin{tabular}{|c|c|c|c|c|}
\hline \multirow{2}{*}{ Type of feature } & \multicolumn{4}{|c|}{ Average values of female players response in formations } \\
\hline & Goalkeepers & Defense & Halfback & Forward \\
\hline Focused on success (M) & $4.00 * 4$ & $3.84 * 4$ & $4.08 * 4$ & $4.75^{* 1,2,3}$ \\
\hline Engaging $(\mathrm{F})$ & $3.37 * 3$ & $2.94 * 3$ & $3.75^{* 1,2,4}$ & $3.00 * 3$ \\
\hline Affectionate (F) & $4.12 * 3$ & $4.15 * 3$ & $4.622^{* 1,2,4}$ & $4.08 * 3$ \\
\hline Capable of sacrifices (F) & $4.62 * 2$ & $3.89 * 1$ & 4.25 & 4.16 \\
\hline Self-confident (M) & 3.50 & $3.15^{* 4}$ & 3.62 & $4.08 * 2$ \\
\hline $\begin{array}{l}\mathrm{F} \text { - features described } \\
\mathrm{M} \text { - features describe } \\
\mathrm{N} \text { - features describe } \\
{ }^{*} \text { - superscript repres } \\
\text { between averages is } \mathrm{s}\end{array}$ & $\begin{array}{l}\text { feminine } \\
\text { masculine } \\
\text { neutral } \\
\text { s the numbe } \\
\text { stically signi }\end{array}$ & $\begin{array}{l}\text { f varia } \\
\text { ant at } t\end{array}$ & $\begin{array}{l}\text { for whi } \\
\text { level } \mathrm{P}<\end{array}$ & $\begin{array}{l}\text { the difference } \\
5\end{array}$ \\
\hline
\end{tabular}

\section{Discussion}

Results of this study, as the results of analyses by Pacut [7] have not authorized the authors to conclude that gender identity uniquely identifies the choice of sport discipline. It should be noted, however, that most of the athletes surveyed had androgynous gender identity. One can, therefore, assume that this is the type of personality that can best adapt to the conditions of functioning in football, or through football by a stereotype defined as androgyny is produced. This conclusion can also be translated into other sports, even so typically "feminine" as artistic gymnastics, synchronized swimming, which accounted for $52.0 \%$ group of athletes with androgynous gender identity (among the respondents female football players accounted for $65.0 \%$ of players of this type) [7].

Also in the case of handball, both in teams of league players, as well as in case of young apprentices of this sport discipline, the androgynous and masculine type was represented in overwhelming majority [15]. Androgyny and masculinity also determined the level of effectiveness of games [16] or simply sporting achievements [17].

It was confirmed that the requirements posed by the most competitive sport disciplines can be described by a set of instrumental behaviours, which are a tool to acquire targets that completely overlap with the pattern of "masculinity", remaining in complete discrepancy with the stereotype of "femininity" [18]. One can most likely assume that every woman undertaking the professional practicing of any sport learns at an accelerated pace such behaviours from the "masculine" repertoire which constitute tools and means to gain success $[19,20]$. The results of the study should be, therefore, explained by the fact that women of 
androgynous type are more independent and assertive, have a higher sense of their value and take up activities typical for both sexes. Androgyny is therefore a "bridge" linking the "masculine" and "feminine" gender schema. In the process of thinking and behaviour it enables flexible use of male and female characteristics. It gives one the best adjustment to act in sport [21]. Androgenic type of women in sport is confirmed by studies of Kłodecka-Różalska and Kownacka [22], who argued that girls practicing judo and fencing, i.e. the combat sports, mostly represented androgynous psychological type, women of "feminine woman" type were in second place.

Features forming the scale of "masculinity": good physical condition, ease of decision-making, selfconfidence, independence, and above all, focus on success necessary in every sport and at every stage of sporting competition, for both women and men [22] authorized to expect presence among respondent female players of a large group with male gender identity, that is, people crosssex-typed. However, there were only $9.6 \%$ players of masculine psychological type, which slightly exceeded the rate of this type of psychological type in the studies of Pacut [7], who among the athletes practicing artistic gymnastics and synchronized swimming found the presence of $3.0 \%$ of athletes with masculine gender identity. These features, which according to cross-cultural gender stereotype were commonly attributed to men or women, in sport cannot be regarded as genre-specific patterns [22]. It is also confirmed by the research of Mroczkowska [18], who concluded that learned psychological readiness to use the model of masculinity was not translated into increased aggressive behaviour of players practicing judo and fencing.

It seems that today there occurs blurring of the distinction between "feminine" and "masculine" disciplines, which to date have reflected the cultural definitions of gender and the treatment of male and female body. "Masculine" sports were those in which violence was present, the brutality, the sheer strength of human muscle, as well as risks, extreme conditions and struggles with the danger. "Feminine" disciplines were those in which the body being in graceful motion and in accordance with the canon of female beauty was presented as an object for viewing [23].

Feminization has become a phenomenon of the late twentieth century, which is reflected in practicing by women of almost all disciplines of sports regardless of the distinction between "masculine" and "feminine". This also applies to football, to practice which individuals with spatial imagination, creative ability, showing great flexibility of response and a rich repertoire of behaviours are predisposed. These are the talents attributed to psychological androgyny exposed in work, which means the integration and complementarity of male and female elements in the personality.

\section{Conclusions}

1. The research hypothesis, assuming that dominance of androgyny (combining strongly expressed in male and female characteristics) fosters athletic career among the football female senior players, the national team under 19 years, and representatives of Polish extra league club has been confirmed.

2. Due to the sense of gender identity Polish female football players turned out to be well prepared for team games, as well for the specific tasks performed on the field. Positive pictures of their ability have been expressed in the data resulting from self-description.

3. The readiness to use in self-description identifying the various dimensions identifying gender stereotypes preferably interacts with the nature of the field activity. Among the forwards (more than in other formations) $83 \%$ represent an androgynous type, confirmed by the frequency of selection of characteristics such as focus on success, confidence and responsibility, about $17 \%$ goalkeepers are the so called "masculine women", who indicate a high degree of ability to make sacrifices, they identify themselves with such features as: a sense of humour, tolerance and responsibility, about $21 \%$ of halfback players are "feminine women", which is expressed in the features such as engagement, emotionality, the pursuit of friendship, tolerance, about $11 \%$ defense players were willing to associate themselves with such qualities as tolerance, sensitivity and sensibility.

4. Players of all formations had in their self-description features of androgyny - stereotypically associated with both "masculinity" and "femininity". Forwards were mostly distinguished by "masculine" focus on success, goalkeepers - "feminine" ability to make sacrifices, and the defense and halfback players - sensitivity regarded as "feminine" characteristic.

5. Positive identification of players with features conducive to achieving success in the team (tolerance, sense of humour, sensitivity, sensibility, attitude toward success) was revealed in all field formations, which was also confirmed by the rejection and denial of behaviours that can impede the interaction (arrogance, domination, naiveté, grumpiness, flirting).

\section{Literature}

1. Soroka, A. (2009). Analysis of ball passes in the final matches of VI Women's Football Championship (England 2005). Sport Wyczynowy 2, 48-59. [in Polish]

2. Szyngiera, W. (2006). The development of women's football in Poland and the world. In J. Bergier (Ed.), Women's Football (pp. 7-18). 2005, Biała Podlaska: PWSZ. [in Polish]

3. Mroczkowska, H. (2003). Psychological gender in the genre inadequate sports tasks of women. Wych. Fiz. Sport 47, 3, 321-328. [in Polish]

4. Aronson, E. (2006). Man a Social Being. PWN. [in Polish] 
5. Mikołajczyk, M. (2003). Does sport have to have gender? In J. Kłodecka-Różalska (Ed.), Sportswoman - a woman of success. Advantages and barriers of women's sports activeness (pp. 24-35). Warsaw: Polskie Stowarzyszenie Sportu Kobiet i Instytut Sportu w Warszawie. [in Polish]

6. Hartman, D. (2003). What can we learn from sport if we take sport seriously as a racial force? Lessons from C.L.R. James's, Beyond a Boundary, Ethnic and Racial Studies. 26(3), 451-483.

7. Pacut, A. (2006). Sense of women's gender identity vs. sports they practice. Sport Wyczynowy 3-4, 35-39. [in Polish]

8. Moir, A. \& Jessel D. (1993). Brain gender. Warsaw: PWN. [in Polish]

9. Bem, S.L. (1997). Psychological androgyny vs. sex identity. In P.G. Zimbardo (Ed.), Psychology and Life. Warsaw, 435. [in Poish]

10. Dulińska, J. \& Duda M. (2002). Emotions of discovery: crossing boundaries of gender identity from the perspective of process-oriented psychology of Arnold Mindell. A paper presented at the interdisciplinary conference "Understanding the gender". Uniwersytet Wrocławski 1-2 czerwca 2002, www.psychologia.net.pl. [in Polish]

11. Kuczyńska, A. (1992). Inventory for Assessment of Psychological Gender. Warsaw: Pracownia Testów Psychologicznych Polskiego Towarzystwa Psychologicznego. [in Polish]

12. Bem, S.L. (2000). Masculinity and Femininity. About Differences Resulting form Sex (116-119). Gdańsk: GWP. [in Polish]

13. Kluczyńska, S. (2001). Masculinity, femininity, androgyny. Niebieska linia 4. [in Polish]

14. Bem, S.L. (1988). Psychical androgyny vs. sex identity. In P.G. Zimbardo \& F.L. Ruch (Eds.), Psychology and life. Warsaw: PWN. [in Polish]
15. Szmajke, A. \& Adamczuk A. (1993). Self-estimation, level of aggressiveness and gender identity. Trening 4, 117-126. [in Polish]

16. Sankowski, T. (1998). Temperamental reactivity and gender identity vs. performance in starting situations. In T. Rychta (Ed.), Personality vs. Targeted Behaviour of Athletes. Warsaw: Biblioteka Trenera, COS. [in Polish]

17. Mikołajczyk, M. (1995). Psychological sex of female athletes and women not practicing sports. In Z. Żukowska (Ed.), Sport in the Lives of Women. Warsaw: Polskie Stowarzyszenie Sportu Kobiet. [in Polish]

18. Mroczkowska, H. (2002). Cultural pattern of "masculinity" vs. social aggressiveness is sports competition. Medycyna Sportowa 18, 2, 311-312. [in Polish]

19. Mroczkowska, H. (2003). Motivation of women in gender-inadequate disciplines. Wych. Fiz. Sport 47, 1, 57-65. [in Polish]

20. Mroczkowska, H. (2007). Conformity with the pattern of maleness and cognitive - motivational determinants of aspirations for success in women. Biol. Sport 24, 275284.

21. Kłodecka-Różalska, J. \& Kownacka I. (2006). Dimensions of psycho-social maturity of girls and boys practicing combat sports. Sport Wyczynowy 11-12, 23-34. [in Polish]

22. Kłodecka-Różalska, J. \& Kownacka I. (2005). Sex stereotype and motivation of achievements of youth practicing combat sports. Sport Wyczynowy 11-12, 23-31. [in Polish]

23. Schneider, M. (2003). Erotic of TV sport. In A. Gwóźdź (Ed.), Media - Eros - Violence. Sport in Times of Pop Culture (79-94). Kraków: Universitas. [in Polish]

Submitted: April 16, 2010

Accepted: December 9, 2010 